\title{
PRESENCE OF BACTERIA IN DENTINAL TUBULES
}

\author{
José Ricardo KINA ${ }^{1}$, Juliana KINA², Eunice Fumico Umeda KINA², Mônica KINA ${ }^{2}$, Ana Maria Pires SOUBHIA ${ }^{3}$
}

1- Division of Periodontics, Department of Surgery and Integrated Clinic, Dental School of Araçatuba, São Paulo State University (UNESP), Araçatuba, SP, Brazil.

2 - Private practice, Araçatuba, SP, Brazil.

3- Department of Pathology, Dental School of Araçatuba, São Paulo State University (UNESP), Araçatuba, SP, Brazil.

Corresponding address: Prof. José Ricardo Kina, Rua José Bonifácio, 1193, Vila Mendonça, 16015-050 - Araçatuba - SP - Brasil

Phone/Fax: +55-18-3636-3200 - e-mail: kinajr@hotmail.com

Received: August 3, 2007 - Modification: November 28, 2007 - Accepted: January 15, 2008

\begin{abstract}
T

his study demonstrated that a significant number of bacteria is present in the radicular dentinal tubules of periodontally diseased human teeth. Ten periodontally diseased teeth were prepared and stained by Brown and Brenn technique for histological examination. Bacteria were detected in all teeth. It is suggested that bacteria may invade dentinal tubules exposed to periodontal pocket and are very hard to be eliminated by conventional mechanical and chemical periodontal therapy. Contaminated dentinal tubules of periodontally diseased teeth can thus act as active bacterial reservoirs to promote recolonization of mechanically treated root surfaces, which could interfere with the periodontal healing and progression of the disease.
\end{abstract}

Key words: Dentin. Bacteria. Infection. Etiology. Periodontal diseases.

\section{INTRODUCTION}

Since bacteria gain access to the periodontal pocket, they can invade the epithelium, connective tissue and radicular hard tissue, such as cementum and dentin, of periodontally diseased teeth ${ }^{15-16,18}$ These sites can serve as bacterial reservoirs from which periodontal bacteria recolonize root surfaces after periodontal therapy ${ }^{16}$.

Dentin is one of the most important root structures that permits bacterial invasion. Depth of bacteria penetration into the dentinal tubules is variable and frequently cannot be reached by mechanical periodontal therapy. Bacterial invasion of dentinal tubules commonly occurs when dentin is exposed following a breach in cementum integrity during periodontal disease ${ }^{1-2,7,11}$. Bacterial products can diffuse through the dentinal tubules towards the periodontal pocket and produce inflammatory changes that will influence periodontal repair and may be responsible for persistence of the periodontal infection.

This study was undertaken in an effort to discuss the importance of dentinal tubule invasion by bacteria originating from periodontal pockets in periodontally diseased human teeth.

\section{MATERIALAND METHODS}

The experimental group consisted of 10 periodontally diseased human teeth with extensive loss of periodontal supporting tissue, which were extracted from 10 fifty-yearold male patients, randomly selected from a private dental office. All participants were fully informed on research purposes and methodology and signed an informed consent form for participation in the study.

All extractions were performed under local anesthesia. Care was taken to avoid mechanical damage to root surface. Immediately after extraction, blood and saliva were removed by rinsing the teeth with sterile saline. No scaling or root planing were performed.

The specimens were fixed in a $10 \%$ neutral buffered formalin solution and decalcified in formic sodium citrate acid. Root segments were prepared for histological analysis in the usual manner, i.e., paraffin embedding, serial sectioning to an average thickness of $6 \mu \mathrm{m}$ and staining by the Brown and Brenn technique ${ }^{4}$.

\section{RESULTS}

Bacteria were identified in all analyzed histological sections.

The histological examination of periodontally diseased human teeth demonstrated that loss of cementum due to periodontal disease exposed the dentinal tubules, allowing penetration of bacteria. Bacterial invasion in dentin occurred to such a depth that would be hard to reach by periodontal 


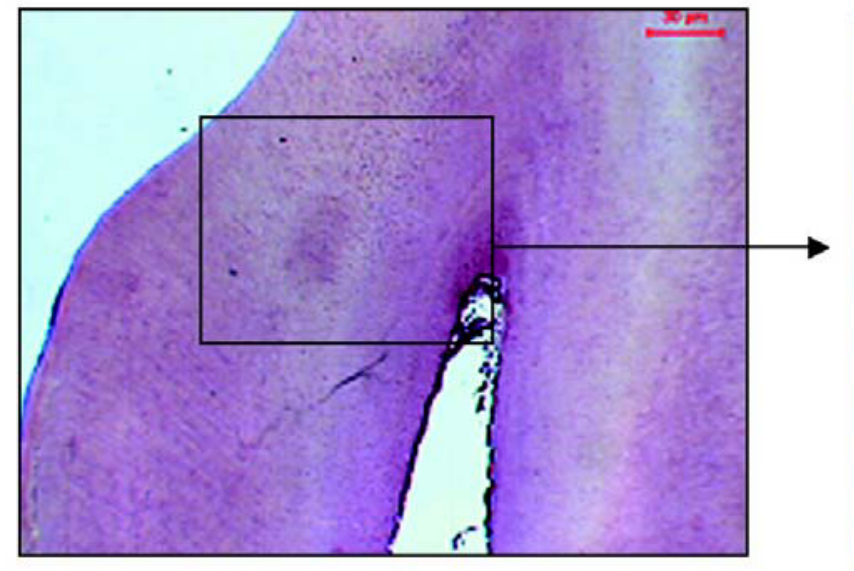

A

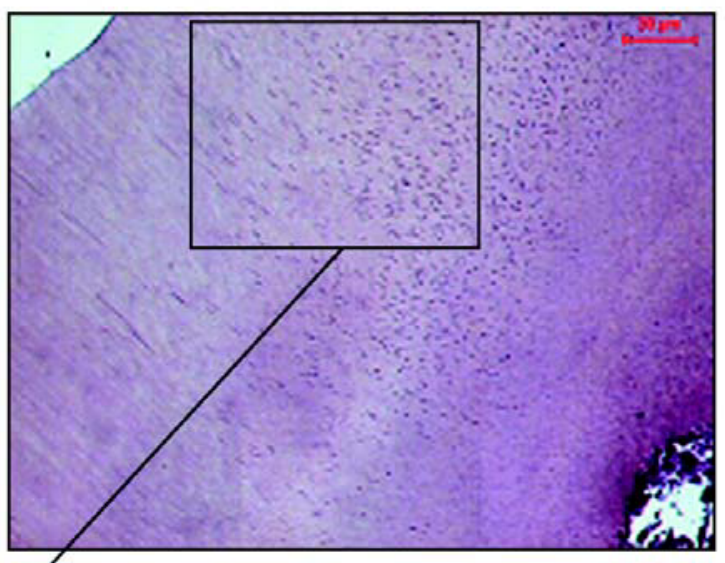

B

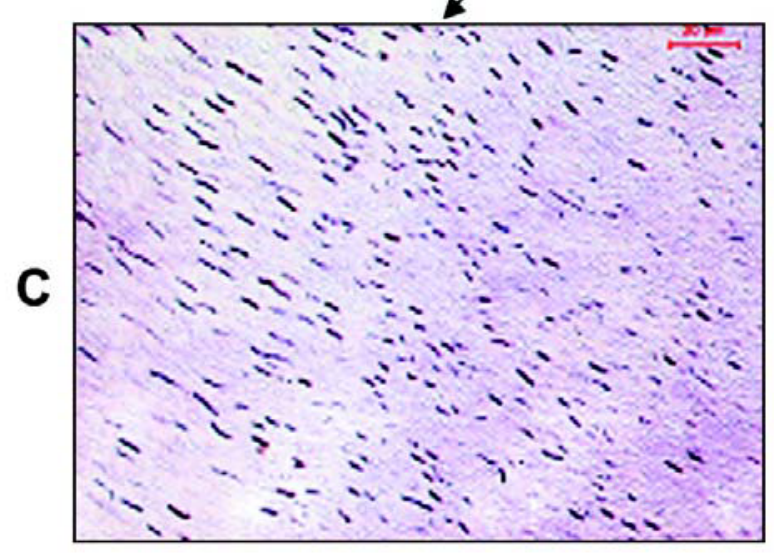

FIGURE 1- A - A survey view of the segments of the roots. B - The loss of cementum exposes dentinal tubules, allowing bacterial invasion of dentin. $\mathrm{C}$ - The bacteria are in depth in the dentin that is difficult to be eliminated by using periodontal mechanical therapy (original magnification, $x 4(A), x 10(B), x 40(C)$

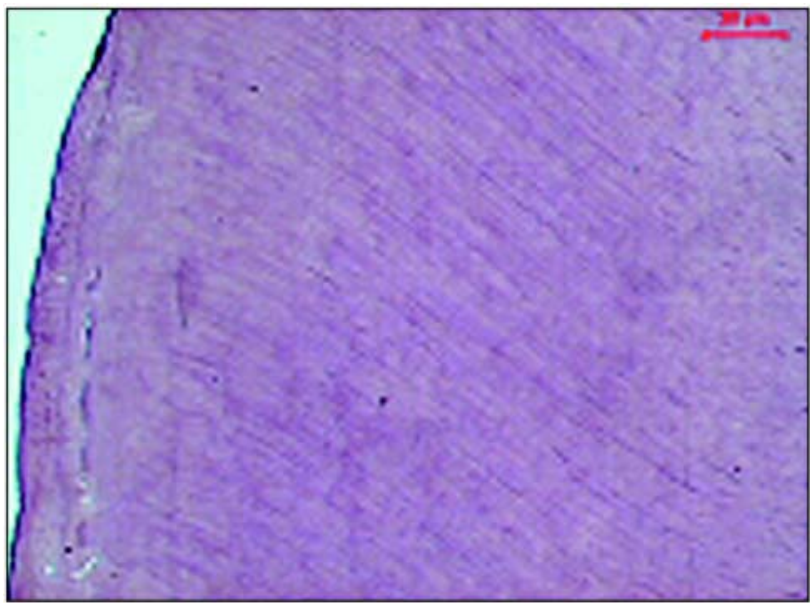

FIGURE 2-When cementum is present over the dentin layer no contamination was observed in dentinal tubules (original magnification $\times 10$ )

\section{therapy (Figure 1).}

No contamination was observed in dentinal tubules when cementum was present over the dentin layer (Figure 2).

\section{DISCUSSION}

An essential change in the bacterial flora of the gingival margin during plaque development is necessary to produce clinical gingivitis. Nevertheless, gingival alterations are dispersed throughout the dentition, and the time required to develop clinical gingivitis varies considerably, despite the fact that bacterial colonization of gingival margin is almost the same in any individual ${ }^{17}$.

Although there is a general agreement that bacteria colonizing and growing at the gingival margin in the gingival sulcus cause inflammation, the mechanism that conducts gingivitis to periodontitis is not completely understood ${ }^{17,27}$. It seems that gingivitis is almost always dependent on endogenous bacterial plaque accumulation and probably aggressive anaerobic bacteria are not predominant in the initial phase of periodontitis. On the other hand, in the periodontal pocket, exogenous anaerobic bacterial plaque is always present and predominant ${ }^{19}$.

As plaque age increases, alterations occur in the relative composition of the bacterial flora. Nevertheless, other etiologic factors have necessarily to act together with bacteria in order to induce periodontitis only in a determined tooth or tooth region ${ }^{14,17}$. Indeed, pocket depth varies in the same 
diseased individual. This means that if periodontal pocket were promoted only by bacteria, periodontal disease would probably be active in all teeth at the same time, producing the same pocket depth with the same bacterial plaque, or only in areas with poor plaque control. The multifactorial etiology of periodontal disease, however, clearly indicates that bacteria alone are not sufficient to produce periodontal pocket. It seems that the initial phase of destructive periodontitis is dependent on the association between endogenous bacteria and other etiologic factors to produce the ideal environment as periodontal pocket to be infected by exogenous anaerobic bacteria. In fact, periodontal disease produces destruction and deep pockets only in some regions (i.e., around a single tooth, in an interproximal space or at one side of a single tooth), which are under influence of other predisposing etiological factors ${ }^{5,22}$. It is thus difficult to find generalized destruction caused by periodontal disease in all teeth of the same patient ${ }^{12,21}$.

When severe periodontitis-induced loss of supporting bone is localized in one tooth, the bacterial species involved in this deep pocket are very different from those of the gingival sulcus of the adjacent teeth ${ }^{10,17,20,23,24,26}$. This phenomenon may be attributed to the fact that contaminant bacteria require an anaerobic favorable environment, such as periodontal pocket, to survive.

When an established gingivitis becomes a destructive periodontitis, pocket formation is the most important clinical and pathological alteration associated with inflammatory periodontal disease ${ }^{27}$. In this stage, etiologic factors of periodontal disease could change mainly the contaminant bacteria that colonize periodontal pockets, as a result of repeated infection by the various species or combinations of species. Considerable variation has been reported in the profile of bacterial species present in subgingival plaque samples from different individuals and from sites of the same individuals. Discreet complexes of bacterial species have been described in association with periodontal disease status and progression ${ }^{26}$. Plaque samples from periodontally healthy subjects consist largely of Gram-positive aerobic species ${ }^{10}$. A shift towards increasing numbers of Gram-negative species occurs in samples from subjects with plaque-induced gingivitis $^{28}$. The flora associated with periodontitis is predominantly Gram-negative, anaerobic and motile ${ }^{20}$. Colonization with a specific periodontal pathogen seems necessary but not sufficient for periodontal disease progression, since most colonized sites remain quiescent for long periods ${ }^{9,25}$. However, some of these Gram-negative anaerobic or facultative anaerobic bacterial species themselves may destruct host defensive cells ${ }^{3}$.

Periodontal tissues are destructed during the short inflammatory acute phase of periodontitis. However, the most prevalent inflammatory phase is chronic and reparative ${ }^{25}$, which always allows repair of the attached connective tissue zone that separates the underlying destructed alveolar bone from the apical end of the pocket epithelium, and also permits repair of the cortical bone inside the bone defects created by periodontal disease ${ }^{12}$. Because of this reparative process, osseous graft surgical procedures require mechanical debridement with curettes and fine rotary instruments in order to promote an intra-marrow penetration into periodontal bone defects, allowing the vascularization ingress and access to osteogenic bone cells in the marrow bone and periodontal ligament before grafting ${ }^{29}$.

Periodontal disease is more quiescent than destructive most part of the time. Although several bacteria that act as primary etiologic factors are present in a stable periodontal pocket, it is likely that they can only restart periodontal destruction if the bacteria-induced inflammatory acute phase occurs at exactly the same time as the inflammatory acute phase determined by other predisposing etiological active factors. All these inflammatory acute processes must act simultaneously to alter the zone of gingival attached connective tissue (biological width), which is the main barrier against destructive phase of periodontal disease. To be coincidental, these acute phases could be aided by other debilitating conditions, such as alterations in host defense mechanisms or even systemic, emotional and local factors.

Bacteria may be inaccessible to mechanical periodontal therapy ${ }^{6}$ in concavities, lacunae and especially in dentinal tubules. Dentinal tubules' microflora associated with a periodontal pocket could act as a reservoir for pocket recolonization ${ }^{1-2,11}$. Most species retrieved from radicular dentin are Gram-positive bacteria, such as P. micros, $S$. intermedius, $A$. naeslundii, with smaller numbers of Gramnegative organisms, such as $P$. gingivalis, $P$. intermedia, Bacteroides forsythus, F. nucleatum and V. parvulla ${ }^{11}$.

Bacterial invasion of dentinal tubules commonly occurs when dentin is exposed following physicochemical and structural alterations of the cementum, such as localized resorptive lacunae or demineralization promoted by bacterial enzymes and acidic metabolites ${ }^{8}$. The depth of bacterial invasion in dentin, which depends in part on the dentinal tubule diameter, may be of such an extent that cannot be reached by conventional mechanical and chemical periodontal therapy.

Bacteria that are able to invade radicular dentin tubules from the periodontal pocket may release bacterial products that diffuse through the dentinal tubules towards the pocket and evoke an inflammatory response, contributing to infection persistence $^{13}$. The conditions under which established but stable periodontitis develops into destructive periodontitis are among the most interesting research issues of periodontology because, in some cases, periodontal lesions remain quiescent for a long time, while in others they cause aggressive breakdown ${ }^{16,25}$.

This study discussed about bacteria, which are primary etiological factors of periodontal disease and will always be present in the mouth, having the potential to invade dentinal tubules during periodontal disease and being hard to eliminate in some cases. However, in spite of the persistence of bacteria in the periodontal tissues, periodontal disease may either be stable and quiescent or cause destruction, depending on whether or not other predisposing etiologic factors act together with the pathogens to develop a coincidental inflammatory destructive acute phase. Preventing and treating periodontitis are thus of key importance to understand, 
diagnose, control and/or eliminate bacteria and other predisposing etiologic factors implicate in this disease.

\section{CONCLUSIONS}

Bacteria may invade dentinal tubules exposed to periodontal pocket and are very hard to be eliminated by conventional periodontal therapy. Contaminated dentinal tubules of periodontally diseased teeth can thus act as active bacterial reservoirs to promote recolonization of mechanically treated root surfaces, which could interfere with the periodontal healing and progression of periodontal disease.

\section{REFERENCES}

1- Adriaens PA, De Boever JA, Loesche WJ. Bacterial invasion in root cementum and radicular dentin of periodontally diseased teeth in humans. A reservoir of periodontopathic bactéria. J Periodontol. 1988;59(4):22230

2- Adriaens PA, Edwards CA, De Boever JA, Loesche WJ. Ultrastructura observations on bacterial invasion in cementum and radicular dentin of periodontally diseased human teeth. J Periodontol. 1988;59(8):493503

3- Baehni P, Tsai CC, McArthur WP, Hammond BF, Taichman NS Interaction of inflammatory cells and oral microorganisms. VIII. Detection of leukotoxic activity of a plaque-derived gram-negative microorganism. Infect Immun. 1979;24(1):233-43.

4- Brown JH, Brenn L. A method for the differential staining of Grampositive and Gram-negative bacteria in tissue sections. Bull Johns Hopkins Hosp. 1931;48:69-73.

5- Buckley LA. The relationships between malocclusion, gingival inflammation, plaque and calculus. J Periodontol. 1981;52(1):35-40.

6- Caffesse RG, Sweeney PL, Smith BA. Scaling and root planing with and without periodontal flap surgery. J Clin Periodontol. 1986;13(3):20510

7- Carrigan P, Morse JDR, Furst ML, Sinai IH. A scanning electron microscopic evaluation of human dentinal tubules according to age and location. J Endod. 1984;10(8):359-63.

8- Daly CG, Seymour GJ, Kieser JB, Corbet EF. Histological assessment of periodontally involved cementum. J Clin Periodontol. 1982;9(3):26674

9- Dzink JL, Socransky SS, Haffajee AD. The predominant cultivable microbiota of active and inactive lesions of destructive periodontal diseases. J Clin Periodontol. 1988;15(5):316-23.

10- Gibbons RJ, Socransky SS, Sawyer S, Kapsimalis B, Macdonald JB The microbiota of the gingival crevice area of man. II. The predominant cultivable organisms. Arch Oral Biol. 1963;8:281-9.

11- Giuliana G, Ammatuna P, Pizzo G, Capone F, D’angelo M. Occurrence of invading bacteria in radicular dentin of periodontally diseased teeth: microbiological findings. J Clin Periodontol. 1997;24(7):478-85.

12- Goodson JM, Tanner AC, Haffajje AD, Sornberger GC, Socransky SS Patterns of progression and regression of advanced destructive periodontal disease. J Clin Periodontol. 1982;9(6):472-81.

13- Haapasalo M. Bacteroides spp. in dental root canal infections. Endod Dent Traumatol. 1989;5(1):1-10.
14- Koral SM, Howell TH, Jeffcoat MK. Alveolar bone loss due to open interproximal contacts in periodontal disease. J Periodontol. 1981;52(8):447-50.

15- Lamont RJ, Chan A, Belton CM, Izutsu KT, Vasel D, Weinberg A. Porphyromonas gingivalis invasion of gingival epithelial cells. Infect Immun. 1995;63(10):3878-85.

16- Listgarten MA. Pathogenesis of periodontitis. J Clin Periodontol. $1986 ; 13(5): 418-30$.

17- Löe H, Theilade E, Jensen SB. Experimental gingivitis in man. J Periodontol. 1965;36:177-87.

18- Manor A, Lebendiger M, Shiffer A, . Bacterial invasion of periodontal tissues in advanced periodontitis in humans. J Periodontol. 1984;55(10):567-73.

19- Moore WE, Holdeman LV, Smibert RM, Good IJ, Burmeister JA, Palcanis KG, et al. Bacteriology of experimental gingivitis in young adult humans. Infect Immun. 1982;38(2):651-67.

20- Newman MG. The role of Bacteroides melaninogenicus and other anaerobes in periodontal infections. Rev Infect Dis. 1979;1(2):313-24.

21- Ormes WM Jr, Sheridan RC Jr. Prevalence of periodontal disease determined by the presence of periodontal pockets alone. J Periodontol. 1965;36:112-4

22- Pennel BM, Keagle JG. Predisposing factors in the etiology of chronic inflammatory periodontal disease. J Periodontol. 1977;48(9):517-32.

23- Slots J. Subgingival microflora and periodontal disease. J Clin Periodontol. 1979;6(5):351-82.

24- Socransky SS. Microbiology of periodontal disease - present status and future considerations. J Periodontol. 1977;48(9):497-504.

25- Socransky SS, Haffajee AD, Goodson JM, Lindhe J. New concepts of destructive periodontal disease. J Clin Periodontol. 1984;11(1):21-32.

26- Socransky SS, Haffajee AD. Periodontal microbial ecology. Periodontol 2000. 2005;38:135-87.

27- Takata T, Donath K. The Mechanism of Procket Formation. A light microscopic study on undecalcified human material. J Periodontol. 1988;59(4):215-21.

28- Theilade E, Wright WH, Jensen SB, Loe H. Experimental gingivitis in man. II. A longitudinal clinical and bacteriological investigation. J Periodontal Res. 1966;1:1-13.

29- Yukna, RA. Synthetic grafts and regeneration. In: Polson, AM. Periodontal Regeneration. Current Status and Directions. Quintessence; 1994. 103-112. 